J. Dairy Sci. 95:5075-5084

http://dx.doi.org/10.3168/jds.2012-5615

(C) American Dairy Science Association ${ }^{\circledR}, 2012$.

\title{
Differences between coagulase-negative Staphylococcus species in persistence and in effect on somatic cell count and milk yield in dairy goats
}

\author{
G. Koop, ${ }^{* 1}$ S. De Vliegher,† A. De Visscher,† K. Supré,‡ F. Haesebrouck,§ M. Nielen, ${ }^{\star}$ and T. van Werven* \\ *Department of Farm Animal Health, Faculty of Veterinary Medicine, Utrecht University, Utrecht, $3584 \mathrm{CL}$, the Netherlands \\ †M-Team and Mastitis and Milk Quality Research Unit, Department of Reproduction, Obstetrics, and Herd Health, Faculty of Veterinary Medicine, \\ Ghent University, Merelbeke, B-9820, Belgium \\ †Milk Control Center Flanders, Lier, B-2500, Belgium \\ $\S$ Department of Pathology, Bacteriology, and Avian Diseases, Faculty of Veterinary Medicine, Ghent University, Merelbeke, B-9820, Belgium
}

\begin{abstract}
Coagulase-negative staphylococci (CNS) are the most commonly isolated bacteria from goat milk. The goal of this study was to explore and describe differences between CNS species in persistence of intramammary infection (IMI) and in effect on somatic cell count (SCC) and milk yield (MY). Milk samples were collected from 530 does from 5 Dutch dairy goat herds on 3 occasions during 1 lactation. Coagulase-negative staphylococci species were identified at the species level by transfer RNA-intergenic spacer PCR (tDNAPCR) followed by capillary electrophoresis. The most prevalent CNS species were Staphylococcus caprae, Staphylococcus epidermidis, Staphylococcus simulans, and Staphylococcus xylosus, but large differences were seen in species distribution between herds. Staphylococcus caprae and Staph. xylosus appeared to be more persistent than other species, but confidence intervals were overlapping. The effect of IMI caused by the 4 most prevalent CNS species on SCC and on MY was determined with linear regression models, and Staph. aureus and Corynebacterium bovis were included in the analyses as reference organisms. Most species were associated with a significantly higher SCC than noninfected udder halves, but the effect of CNS species on SCC was much smaller than the effect of Staph. aureus on SCC. We found a significant positive association between infection with Staph. caprae and MY. Intramammary infection caused by Staph. xylosus, on the other hand, had a negative association with milk yield, comparable to the effect of Staph. aureus, but these effects were not significantly different from zero. Intramammary infections with CNS species have a high prevalence in goats
\end{abstract}

Received April 12, 2012.

Accepted May 20, 2012.

${ }^{1}$ Corresponding author: g.koop@uu.nl and are persistent, but have a limited effect on SCC compared with IMI with Staph. aureus. The effect of CNS species on MY differed between species, but differences were nonsignificant because limited numbers per species were available for analysis. Therefore, CNS species appear to behave as minor pathogens in goats, but larger studies are needed to give better estimates for the effect on MY.

Key words: coagulase-negative staphylococci, goat, transfer RNA-intergenic spacer PCR (tDNA-PCR), somatic cell count

\section{INTRODUCTION}

In dairy goats, the majority of subclinical IMI are caused by CNS species (Bergonier et al., 2003; Contreras et al., 2007). Research on differences in pathogenicity between CNS species cultured from goat milk is scarce. The pathogenicity or virulence of udder pathogens may be described by their potential to increase SCC, decrease milk yield (MY), and cause clinical mastitis. In addition, the ability to cause a persistent infection can be an indicator of pathogenicity, but only if other aspects of pathogenicity are present. In cows, some CNS species were shown to be more pathogenic than others, and differences in persistence have been described (Piessens et al., 2011; Supré et al., 2011). In goats, research on pathogenicity of CNS species used phenotypic methods, rather than molecular methods, for identifying CNS species. These studies focused mainly on the effect of infection on SCC or California Mastitis Test results (Maisi and Riipinen, 1991; Deinhofer and Pernthaner, 1995; Contreras et al., 1999; Moroni et al., 2005a) and on persistence of infection (Contreras et al., 1997; Moroni et al., 2005a), but to our knowledge did not describe the effect on MY. Because clinical mastitis caused by CNS is rare in goats (Contreras et al., 2003), differences between species in ability to cause clinical mastitis are assumed to be small. 
In this study, a genotypic method was used to identify CNS isolates from Dutch goat milk samples to the species level. The goal of the paper was to describe differences between CNS species in persistence and in effect on SCC and MY.

\section{MATERIALS AND METHODS}

\section{Study Design and Animal Selection}

The longitudinal prospective field study conducted for this paper was described previously (Koop et al., 2010). Briefly, 5 farms were enrolled and 100 does each were selected on 4 of them, whereas 130 does were selected on 1 farm. About $30 \%$ of the selected goats were yearlings, about $30 \%$ were about to start a second lactation, and about $40 \%$ were older animals. On one farm, no animals of parity $\geq 3$ were available, and about $70 \%$ of the selected animals were of parity 2 . On the farm where 130 does were selected, the percentage of yearling does was $26 \%$. All animals were of the Saanen breed or Saanen crosses. All herds were certified free from caprine arthritis encephalitis virus except 1 , but no clinical signs had been observed for many years in that herd.

The enrolled goats were sampled 3 times during 1 lactation. The first sampling was carried out between 4 and 42 DIM, the second sampling was scheduled 6 wk later, and the final sampling took place within 2 mo after introduction of the breeding bucks. The time of breeding varied between herds, so the final sampling took place between 170 and 285 DIM. The does were selected based on the farmers' information on which animals were in early lactation at the time of first sampling, and exact kidding dates were obtained from the farmers' management systems after conclusion of the study. If animals turned out to be more than 42 DIM at the first sampling occasion, the effect of exclusion of these animals from the analyses on SCC effect was assessed, because of the known relationship between DIM and SCC in goats (Koop et al., 2010).

Duplicate foremilk samples for bacteriological culture and SCC measurement were collected repeatedly from both udder halves on each of the sampling occasions during the morning milking. The first 3 squirts of milk were discarded and teat ends were scrubbed with a cotton ball soaked in alcohol before each sample was taken. About $8 \mathrm{~mL}$ of milk per sample was collected in plastic vials and cooled with icepacks. The samples were shipped immediately after completion of a herd sampling to the Milk Control Center Flanders (Lier, Belgium) for bacteriological culture and SCC measurement.
Milk yield data were collected through regular DHI sampling. These samplings were scheduled within $2 \mathrm{~d}$ from a sampling for bacteriological culture.

\section{Bacteriological Procedures}

In short, $0.01 \mathrm{~mL}$ of milk was streaked onto a quarter of an esculin blood agar plate (Gibco Technologies, Paisley, UK) and incubated at 35 to $37^{\circ} \mathrm{C}$. The samples were incubated for $48 \mathrm{~h}$ if no growth was detected after $24 \mathrm{~h}$. Bacteria were classified following National Mastitis Council guidelines (Hogan et al., 1999). Any sample yielding 3 or more different types of bacteria was considered contaminated.

Coagulase-negative staphylococci were stored in brain-heart infusion broth with $15 \%$ (wt/vol) glycerol at $-80^{\circ} \mathrm{C}$ until further identification.

\section{CNS Species Identification}

Only CNS that were cultured from both duplicate samples were subjected to species identification. The stored isolates were regrown on Colombia agar plates supplemented with 5\% sheep blood (Oxoid, Basingstoke, UK), and DNA was prepared by alkaline extraction according to Baele et al. (2000). The CNS species were identified using transfer RNA-intergenic spacer PCR (tDNA-PCR) followed by capillary electrophoresis as described by Supré et al. (2009).

\section{Definition of IMI}

An udder half was considered infected if both duplicate samples yielded growth of at least one colony of the same type of pathogen, where all CNS species were considered to be the same type, based on growth characteristics. If 1 of the 2 duplicate samples was contaminated or showed no growth, the udder half was analyzed as noninfected. If the 2 duplicates yielded 2 different CNS species, the udder half was classified as noninfected for further analysis. If the CNS species cultured from the first or the second sample could not be identified, the udder half was considered infected with the species cultured from the other sample.

\section{Statistical Analyses}

To assess the agreement between CNS species identified in the first and second of the duplicate milk samples, the kappa $(\kappa)$ statistic was calculated. Samples that could not be identified with the tDNA-PCR technique were excluded from this analysis. 
Persistence of infection with CNS species was determined by calculating the fraction of udder half samples infected with a particular species at the first sampling that were still infected with the same species on the second and third sampling occasions. Persistence of IMI with Staph. aureus and C. bovis was also calculated as a reference. Only udder halves with no missing or contaminated culture results at all 3 sampling occasions were included in this analysis. Incidence of new infections was calculated as the fraction of udder halves infected with a particular species at the second sampling that were culture negative at the first sampling and the fraction infected with a particular species at the third sampling that were culture negative at the second sampling.

The effect of CNS species on SCC was assessed by means of a linear mixed model with udder half as observational unit and $\log _{10}$-transformed SCC (logSCC) as dependent variable. The independent variable of primary interest was the categorical variable IMI status (IMI), with 9 classes: 4 classes for the 4 most prevalent CNS species, noninfected, C. bovis-infected, Staph. aureus-infected, CNS-infected (other species or species not identified), and infected with other pathogens. Possible confounders that were tested in the backward selection model building process were udder half position (HALF; left or right), parity (PAR; 1, 2, 3, or 4 and higher), milk yield (MY, $\mathrm{kg} / \mathrm{d}$ ), and sampling occasion (SAMP; first, second, or third). Variables were kept in the model if they had a significant association with the dependent variable, based on the likelihood ratio test, or if they had a confounding effect on the relationship between infection status and logSCC $(>20 \%$ change in $\beta$-estimate was deemed an indicator of confounding). First-order autoregressive and compound symmetry covariance structures were considered and the covariance structure with the lowest Akaike's information criterion (AIC) was included if it yielded a significant improvement of the model. The assumptions of homoscedasticity, normality, and linearity were checked by visual inspection of the plots of standardized residuals against standardized predicted values, quantile-quantile plots of standardized residuals, and plots of standardized residuals against predictor variables. The final model was as follows:

$$
\begin{array}{r}
\log \mathrm{SCC}_{\mathrm{ijkl}}=\mu+\mathrm{IMI}_{\mathrm{ijkl}}+\mathrm{HALF}_{\mathrm{ijk}}+\mathrm{PAR}_{\mathrm{ij}}+\mathrm{MY}_{\mathrm{ijl}} \\
+\mathrm{SAMP}_{\mathrm{ijkl}}+\rho_{\mathrm{i}}+\sigma_{\mathrm{ij}}+\tau_{\mathrm{ijk}}+\mathrm{e}_{\mathrm{ijkl}},
\end{array}
$$

where $\operatorname{logSCC} \mathrm{S}_{\mathrm{ijk}}$ is the dependent variable, $\mathrm{i}$ corresponds to the ith herd, $\mathrm{j}$ corresponds to the jth goat, $\mathrm{k}$ corresponds to the kth udder half, $\mathrm{l}$ corresponds to the lth sampling occasion, $\mu$ represents the intercept, $\rho_{\mathrm{i}}$ represents the random variation for the ith herd, $\sigma_{\mathrm{ij}}$ represents the repeated variation of the jth goat within the ith herd, $\tau_{\mathrm{ijk}}$ represents the repeated variation of the kth udder half of the jth goat in the ith herd, and $\mathrm{e}_{\mathrm{ijk} \mathrm{k}}$ represents residual error. Comparable models, but with a different IMI categorization than given above (with CNS species clustered as a single group and with all 16 CNS species separately) were also run.

The effect of CNS species on MY was studied by means of a linear mixed regression model with goat as observational unit and MY $(\mathrm{kg} / \mathrm{d})$ as dependent variable. Because MY was recorded at the goat level, IMI status was also categorized at the goat level. An animal was considered infected if one or both halves were positive for a certain pathogen. If 2 different species of CNS were cultured within the same goat, the goat was analyzed as "other CNS species." If a CNS species and $C$. bovis were cultured within the same goat, the goat was classified as "C. bovis and CNS infected." Combinations of Staph. aureus and any other pathogen were classified as "Staph. aureus-infected." Combinations of other infections with CNS species or C. bovis or uninfected halves were classified as "other infections." The model building process was as described for the SCC model. The lactation curve was modeled by including weeks in milk (WIM) as a fixed factor. Sampling occasion was thus not included in the model. The final model had the following form:

$$
\begin{aligned}
\mathrm{MY}_{\mathrm{ijl}}=\mu & +\mathrm{IMI}_{\mathrm{ijl}}+\mathrm{PAR}_{\mathrm{ij}}+\mathrm{WIM}_{\mathrm{ijl}} \\
& +\rho_{\mathrm{i}}+\sigma_{\mathrm{ij}}+\mathrm{e}_{\mathrm{ijl}},
\end{aligned}
$$

with variables as defined above.

The analyses were performed in $\mathrm{R}$ (version 2.11.0; R Foundation for Statistical Computing, Vienna, Austria). For the mixed model, the LME function from the NLME library was used (Pinheiro et al., 2009). Confidence intervals around fractions were calculated using the binconf function from the Hmisc library (Harrell, 2004).

\section{RESULTS}

\section{Descriptive Statistics}

Culture Results. Data from 39 animals were lost because the exact kidding date could not be retrieved or because animals were missed during sampling. The total number of animals with culture results was therefore 491. Table 1 gives an overview of the culture results 
Table 1. Culture results from udder half samples from 491 dairy goats in 5 Dutch herds, sampled at 3 occasions in lactation

\begin{tabular}{|c|c|c|c|c|c|c|c|c|}
\hline \multirow[b]{2}{*}{ Culture result } & \multicolumn{2}{|c|}{$\begin{array}{c}\text { Early-lactation } \\
\text { udder halves }\end{array}$} & \multicolumn{2}{|c|}{$\begin{array}{l}\text { Peak-lactation } \\
\text { udder halves }\end{array}$} & \multicolumn{2}{|c|}{$\begin{array}{c}\text { Late-lactation } \\
\text { udder halves }\end{array}$} & \multicolumn{2}{|c|}{$\begin{array}{l}\text { All udder } \\
\text { halves }\end{array}$} \\
\hline & No. & $\%$ & No. & $\%$ & No. & $\%$ & No. & $\%$ \\
\hline Corynebacterium bovis & 221 & 22.6 & 184 & 19.2 & 258 & 28.2 & 663 & 23.2 \\
\hline CNS & 114 & 11.6 & 122 & 12.7 & 119 & 13.0 & 355 & 12.4 \\
\hline Staphylococcus aureus & 13 & 1.3 & 18 & 1.9 & 13 & 1.4 & 44 & 1.5 \\
\hline Streptococcus dysgalactiae & 1 & 0.1 & 2 & 0.2 & 1 & 0.1 & 4 & 0.1 \\
\hline Gram-negative spp. & 1 & 0.1 & 1 & 0.1 & 1 & 0.1 & 3 & 0.1 \\
\hline Bacillus spp. & 1 & 0.1 & 0 & 0.0 & 0 & 0.0 & 1 & 0.0 \\
\hline Yeast & 0 & 0.0 & 1 & 0.1 & 0 & 0.0 & 1 & 0.0 \\
\hline Contaminated & 11 & 1.1 & 25 & 2.6 & 11 & 1.2 & 47 & 1.6 \\
\hline Total & 979 & 100.0 & 959 & 100.0 & 916 & 100.0 & 2,854 & 100.0 \\
\hline
\end{tabular}

on the 3 sampling occasions. A high prevalence of $C$. bovis was found. This pathogen, however, was only seen in large numbers in herds 3 and 4.

CNS Species Distribution. In 185 cases, CNS were cultured in only 1 of the 2 duplicate samples. From 411 udder halves, CNS were cultured from both duplicate samples, and 820 isolates were subjected to further speciation with the tDNA-PCR technique. The tDNA-PCR analysis failed for both duplicates from 25 udder-half samplings due to technical issues. In 4 cases, both duplicates gave a result that could not be interpreted through the tDNA-PCR method because of nonmatching with the library. Because of funding constraints, no further sequencing could be done, so these udder halves were analyzed as failed or unidentified. In 38 cases, 2 different CNS species were identified from the 2 duplicate samples, and these udder halves were defined as being noninfected.

The $\kappa$-value for the agreement between the first and second duplicate sample was 0.83 (95\% CI: 0.78 to 0.88). Table 2 shows that Staph. caprae, Staph. epidermidis, Staph. simulans, and Staph. xylosus were the 4 most prevalent species and that distribution of species differed between herds.

Table 2. Distribution of CNS species over 5 Dutch dairy goat herds, based on 3 repeated udder-half samples during 1 lactation ${ }^{1}$

\begin{tabular}{|c|c|c|c|c|c|c|c|c|c|c|c|c|}
\hline \multirow[b]{2}{*}{ Species } & \multicolumn{2}{|c|}{$\begin{array}{c}\text { Herd } 1 \\
\text { udder halves }\end{array}$} & \multicolumn{2}{|c|}{$\begin{array}{c}\text { Herd } 2 \\
\text { udder halves }\end{array}$} & \multicolumn{2}{|c|}{$\begin{array}{c}\text { Herd } 3 \\
\text { udder halves }\end{array}$} & \multicolumn{2}{|c|}{$\begin{array}{c}\text { Herd } 4 \\
\text { udder halves }\end{array}$} & \multicolumn{2}{|c|}{$\begin{array}{c}\text { Herd } 5 \\
\text { udder halves }\end{array}$} & \multicolumn{2}{|c|}{$\begin{array}{c}\text { Total } \\
\text { udder halves }\end{array}$} \\
\hline & No. & $\%$ & No. & $\%$ & No. & $\%$ & No. & $\%$ & No. & $\%$ & No. & $\%$ \\
\hline Staph. caprae & 45 & 34.4 & 17 & 41.5 & 1 & 3.1 & 25 & 28.1 & 31 & 62.0 & 119 & 34.7 \\
\hline Staph. epidermidis & 39 & 29.8 & 0 & 0.0 & 19 & 59.4 & 8 & 9.0 & 3 & 6.0 & 69 & 20.1 \\
\hline Staph. simulans & 23 & 17.6 & 7 & 17.1 & 6 & 18.8 & 11 & 12.4 & 7 & 14.0 & 54 & 15.7 \\
\hline Staph. xylosus & 7 & 5.3 & 10 & 24.4 & 0 & 0.0 & 22 & 24.7 & 5 & 10.0 & 44 & 12.8 \\
\hline Staph. chromogenes & 11 & 8.4 & 1 & 2.4 & 1 & 3.1 & 2 & 2.2 & 0 & 0.0 & 15 & 4.4 \\
\hline Staph. lugdunensis & 0 & 0.0 & 0 & 0.0 & 3 & 9.4 & 12 & 13.5 & 0 & 0.0 & 15 & 4.4 \\
\hline Staph. hemolyticus & 3 & 2.3 & 0 & 0.0 & 1 & 3.1 & 0 & 0.0 & 2 & 4.0 & 6 & 1.7 \\
\hline Staph. croceolyticus & 0 & 0.0 & 2 & 4.9 & 0 & 0.0 & 2 & 2.2 & 0 & 0.0 & 4 & 1.2 \\
\hline Staph. arlettae & 1 & 0.8 & 0 & 0.0 & 0 & 0.0 & 2 & 2.2 & 0 & 0.0 & 3 & 0.9 \\
\hline Staph. capitis & 1 & 0.8 & 0 & 0.0 & 0 & 0.0 & 2 & 2.2 & 0 & 0.0 & 3 & 0.9 \\
\hline Staph. warneri & 0 & 0.0 & 3 & 7.3 & 0 & 0.0 & 0 & 0.0 & 0 & 0.0 & 3 & 0.9 \\
\hline Staph. auricularis & 0 & 0.0 & 1 & 2.4 & 0 & 0.0 & 1 & 1.1 & 0 & 0.0 & 2 & 0.6 \\
\hline Staph. gallinarum & 0 & 0.0 & 0 & 0.0 & 0 & 0.0 & 2 & 2.2 & 0 & 0.0 & 2 & 0.6 \\
\hline Staph. lentus & 0 & 0.0 & 0 & 0.0 & 0 & 0.0 & 0 & 0.0 & 2 & 4.0 & 2 & 0.6 \\
\hline Staph. cohnii & 0 & 0.0 & 0 & 0.0 & 1 & 3.1 & 0 & 0.0 & 0 & 0.0 & 1 & 0.3 \\
\hline Staph. rostri & 1 & 0.8 & 0 & 0.0 & 0 & 0.0 & 0 & 0.0 & 0 & 0.0 & 1 & 0.3 \\
\hline Total CNS & 131 & 100.0 & 41 & 100.0 & 32 & 100.0 & 89 & 100.0 & 50 & 100.0 & 343 & 100.0 \\
\hline Staph. aureus & 17 & & 1 & & 11 & & 9 & & 6 & & 44 & \\
\hline C. bovis & 6 & & 0 & & 439 & & 213 & & 5 & & 663 & \\
\hline
\end{tabular}

\footnotetext{
${ }^{1}$ The numbers of Staphylococcus aureus and Corynebacterium bovis were included for comparison.
} 
Table 3. Number of udder halves infected with a CNS species at the first sampling occasion and fraction of udder halves that were still infected with the same species at the second and third sampling occasions ${ }^{1}$

\begin{tabular}{lccc}
\hline Species & $\begin{array}{c}\text { Number at } \\
\text { sampling } 1\end{array}$ & $\begin{array}{c}\text { Fraction at sampling } 2 \\
(95 \% \text { CI })\end{array}$ & $\begin{array}{c}\text { Fraction at sampling } 3 \\
(95 \% \text { CI })\end{array}$ \\
\hline Staph. caprae & 30 & $0.87(0.70-0.95)$ & $0.53(0.36-0.70)$ \\
Staph. epidermidis & 23 & $0.61(0.41-0.78)$ & $0.35(0.19-0.55)$ \\
Staph. simulans & 20 & $0.45(0.26-0.66)$ & $0.35(0.18-0.57)$ \\
Staph. xylosus & 15 & $0.93(0.70-1.00)$ & $0.60(0.36-0.80)$ \\
Staph. lugdunensis & 4 & $0.75(0.30-0.99)$ & $0.75(0.30-0.99)$ \\
Staph. chromogenes & 3 & $0.33(0.02-0.79)$ & $0.33(0.02-0.79)$ \\
Staph. capitis & 1 & $0.00(0.00-0.95)$ & $0.00(0.00-0.95)$ \\
Staph. croceolyticus & 1 & $0.00(0.00-0.95)$ & $0.00(0.00-0.95)$ \\
Staph. gallinarum & 1 & $1.00(0.05-1.00)$ & $0.00(0.00-0.95)$ \\
Staph. hemolyticus & 1 & $0.00(0.00-0.95)$ & $0.00(0.00-0.95)$ \\
Staph. warneri & 1 & $1.00(0.05-1.00)$ & $1.00(0.05-1.00)$ \\
Staph. aureus & 12 & $0.83(0.55-0.95)$ & $0.50(0.25-0.75)$ \\
C. bovis & 203 & $0.72(0.66-0.78)$ & $0.61(0.54-0.68)$ \\
\hline Staphyl & &
\end{tabular}

${ }^{1}$ Staphylococcus aureus and Corynebacterium bovis were included as reference.

\section{Persistence and Incidence of Infection}

Table 3 gives the persistence of infection per species over the 3 consecutive sampling occasions. Staphylococcus caprae and Staph. xylosus had a persistency comparable to that of Staph. aureus and appeared to be somewhat more persistent than other species, but confidence intervals were overlapping for all species. The incidence of infection was low for all Staphylococcus species (including Staph. aureus) compared with $C$. bovis (Table 4).

\section{Association with SCC}

The logSCC of udder halves infected with most CNS species was significantly higher than that of noninfected udder halves (Figure 1a). The inclusion of the

Table 4. Percentage of udder halves that were uninfected at sampling $1(\mathrm{n}=580)$ or sampling $2(\mathrm{n}=559)$ and that were infected with a CNS species, Staphylococcus aureus, or Corynebacterium bovis at sampling 2 or 3 , respectively

\begin{tabular}{lcc}
\hline Species & $\begin{array}{c}\text { New infections at } \\
\text { sampling 2 }(\%)\end{array}$ & $\begin{array}{c}\text { New infections at } \\
\text { sampling 3 }(\%)\end{array}$ \\
\hline Staph. caprae & 1.4 & 2.7 \\
Staph. epidermidis & 1.0 & 1.1 \\
Staph. simulans & 0.7 & 0.9 \\
Staph. chromogenes & 0.3 & 0.0 \\
Staph. croceolyticus & 0.2 & 0.2 \\
Staph. lentus & 0.0 & 0.4 \\
Staph. lugdunensis & 0.2 & 0.2 \\
Staph. arlettae & 0.0 & 0.2 \\
Staph. capitis & 0.0 & 0.2 \\
Staph. hemolyticus & 0.0 & 0.2 \\
Staph. xylosus & 0.2 & 0.0 \\
Total CNS species & 4.0 & 5.9 \\
Staph. aureus & 0.5 & 0.2 \\
C. bovis & 5.9 & 16.5 \\
Total new infections & 10.3 & 22.5 \\
\hline
\end{tabular}

4 most prevalent CNS species in the model separately and all other CNS species clustered resulted in a lower AIC than the inclusion of all CNS species as one group and had a comparable AIC as the model with all 16 different CNS species modeled separately. The final model contained a first-order autoregressive covariance structure. According to the information from the farm management system, 12 animals turned out to be more than 42 DIM at the first sampling occasion. Exclusion of these does from the data set did not change the model results significantly, so the results from the total data set are presented. Exclusion of the covariate MY from the model did not greatly affect the estimates for the CNS species. Figure 1a shows that the relationship of most CNS infections with logSCC was stronger than that of infection with C. bovis, and that all CNS species infections had a much weaker association with logSCC than did infection with Staph. aureus. Differences in association with $\operatorname{logSCC}$ between the CNS species were small.

\section{Association with MY}

Lower MY was seen for does infected with Staph. xylosus and with Staph. aureus, whereas significantly higher MY was associated with Staph. caprae infection relative to the reference category (noninfected goats; Figure 1b). The final model had a first-order autoregressive covariance structure. Exclusion of animals with a too high DIM had little effect on the estimates. Inclusion of logSCC in the model changed the estimate for Staph. aureus from -0.33 (95\% CI: $-0.78-0.12)$ to -0.19 (95\% CI: -0.64-0.27) and that for Staph. simulans from 0.37 (95\% CI: $-0.11-0.85)$ to 0.50 (95\% CI: $0.02-0.98)$. The estimates for the other species were insensitive to inclusion of logSCC. 
a)

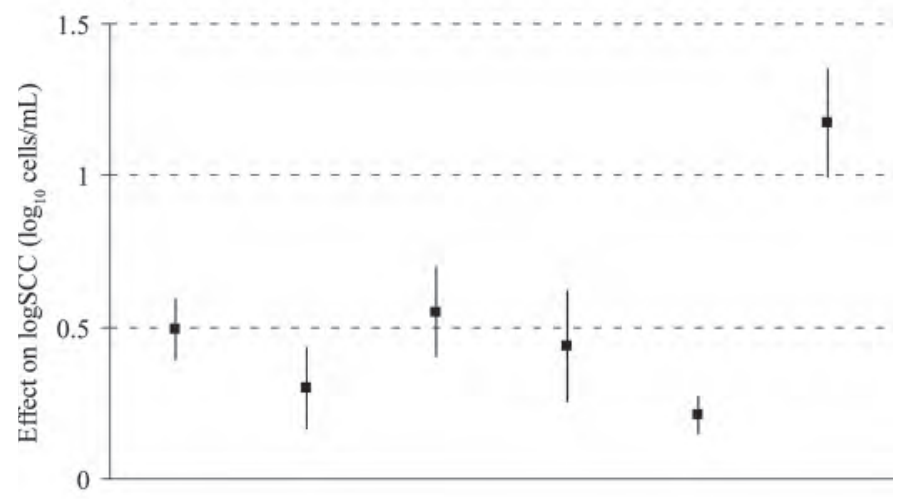

b)

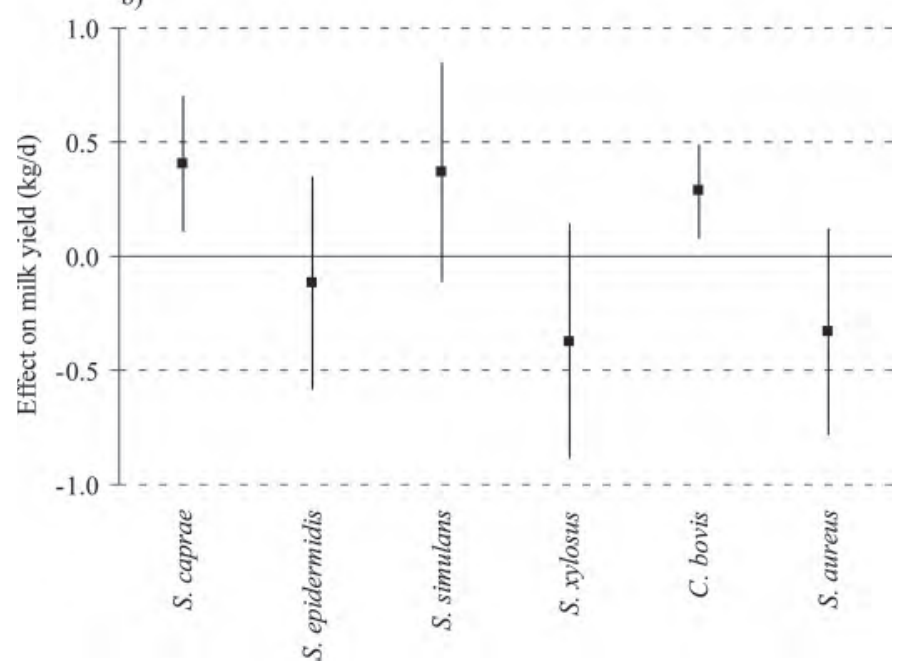

Figure 1. (a) Estimates $(\beta)$ and $95 \%$ CI of the effect of udder half infection with each of the 4 most prevalent CNS species (Staph. caprae, Staph. epidermidis, Staph. simulans, and Staph. xylosus), Staph. aureus, or Corynebacterium bovis on $\log _{10}$-transformed SCC (logSCC), obtained from model [1], based on 2,809 records from 977 udder halves of 490 goats in 5 herds; and (b) estimates $(\beta)$ and $95 \%$ CI of the effect of udder infection with each of the 4 most prevalent CNS species, Staph. aureus, or C. bovis on milk yield, obtained from model [2], based on 1,414 records from 490 goats in 5 herds.

\section{DISCUSSION}

\section{Descriptive Statistics}

Using tDNA-PCR, we were able to identify the majority of CNS species cultured from goat milk samples. The most prevalent species were the same as those described in the literature, although in most previous studies Staph. epidermidis was more prevalent than Staph. caprae (e.g., Poutrel, 1984; Deinhofer and Pernthaner, 1995; Moroni et al., 2005b). This may be explained by the fact that previous studies used phenotypic tests (most often API Staph, BioMérieux, Marcy l'Etoile,
France), but may also reflect differences in distribution between countries with, for example, different housing and management systems. However, the number of herds in our study was limited and large differences in species distribution were seen between herds, so the distribution of CNS species in our sample may not reflect the distribution in the population. Differences in CNS distribution between herds have also been described in studies in cows (Thorberg et al., 2009; Piessens et al., 2011; Supré et al., 2011). Piessens et al. (2011) and Supré et al. (2011) hypothesized that herd-level factors may be involved in the establishment of a particular CNS species in a herd. Contreras et al. (2003) also suggested that the presence of different CNS species might be attributed to herd-specific mastitis-control practices, such as teat dipping or dry-off treatment.

Staphylococcus caprae was the most frequently detected CNS species in our study, but it has rarely been cultured from cow milk samples (Park et al., 2011). It is more common in sheep (Onni et al., 2010; Pilipčincová et al., 2010) but less common than in goats. The species was first described by Devriese et al. (1983) and although it is associated with goats, it has been involved in human nosocomial infections (Ross et al., 2005; Arciola et al., 2006). Staphylococcus caprae has been cultured from milk samples from subclinically infected goats, but also from clinical mastitis cases (Deinhofer and Pernthaner, 1995) and from udder and teat skin of healthy goats (Valle et al., 1991). It is unknown why this species is restrained to small ruminant species and why it infects the cow's udder so rarely. In cows, Staph. chromogenes and Staph. simulans are the predominant CNS species causing IMI (Pyörälä and Taponen, 2009); however, in several studies, Staph. xylosus, Staph. epidermidis, Staph. hemolyticus, and Staph. cohnii were also seen at high frequency (Sampimon et al., 2009; Thorberg et al., 2009; Piessens et al., 2011; Supré et al., 2011). The same species were common in our study.

\section{tDNA-PCR}

The tDNA-PCR technique is valuable because of its high accuracy, fast throughput time, and low cost ( $\mathrm{Su}-$ pré et al., 2009). Currently, gene sequencing is generally more expensive and labor demanding. However, the advantages of gene sequencing over the technique used in this study are the availability of a larger reference database and the fact that it gives a quantitative measure of the certainty with which an isolate has been identified (Zadoks and Watts, 2009). One species (Staph. croceolyticus) could not be identified by tDNA-PCR, because it was not included in the library. Gene sequencing was required to identify these isolates, and the tDNA-PCR 
patterns of these isolates were subsequently added to the tDNA library. Although sequencing data of this species were already deposited in the National Center for Biotechnology Information database (http://blast. ncbi.nlm.nih.gov/), a valid description of it is still lacking. Strain differences appear to exist between goat and bovine Staph. xylosus isolates, because we observed a clear distinction between bovine and caprine $S$. xylosus tDNA-PCR clusters. This hampers identification by tDNA-PCR, and gene sequencing was performed to confirm the identity of these isolates. If no clear tDNAPCR result was reached for an isolate because of the lack of a good matching tDNA-PCR fingerprint in the library, gene sequencing was performed. However, because of funding constraints, gene sequencing was not carried out on 34 presumptively identified isolates (14 Staph. simulans, 8 Staph. hemolyticus, 6 Staph. arlettae, 4 Staph. lentus, and 2 Staph. gallinarum). In 11 cases, 2 of the isolates were cultured in duplicate from the same udder half, so the actual number of udder-half infections that was identified with suboptimal certainty was 23 . The agreement ( $\kappa$-value) between species cultured from the first and second of the duplicate samples was good (Petrie and Watson, 2006). Discrepant pairs can be explained by the occurrence of mixed infections. Because CNS infections are relatively common, some mixed infections of 2 species are to be expected based on chance.

\section{Persistence of Infection}

Because no strain typing was performed, we could not differentiate between re-infection of the same udder half with the same species and persistent infection. Therefore, persistency may have been overestimated, but because of the low incidence, this overestimation is probably limited. In this study, Staph. xylosus and Staph. caprae appeared to be more persistent than other species, although differences between species were small and confidence intervals were overlapping. When comparing our findings with those in the literature, it is important to remember that older studies used phenotypic identification methods and therefore some misclassification may have occurred. Previous papers did not report on the persistence of Staph. xylosus, but it has been reported that Staph. caprae had lower persistence than Staph. epidermidis during lactation (Moroni et al., 2005a) or across the dry period (Poutrel, 1984), opposite to what we found in the current study. Contreras et al. (1997) studied persistence of CNS infections with monthly samplings over a 7 -mo period. The most persistent isolates were Staph. chromogenes and Staph. xylosus, which is partly in agreement with our findings.
Most of these persistent infections lasted for up to the 7 mo of the study period. Persistence of infection was high for Staph. aureus in our study, underscoring the known pathogenicity of this species as a mastitis pathogen in goats (Contreras et al., 2003). Still, persistency per se is not necessarily an indicator of pathogenicity, because more virulent pathogens may cause a very brief but severe disease. However, in the case of subclinical IMI, chronicity may cause more MY loss and increases the chances of transmission to other animals.

\section{Association with SCC}

Coagulase-negative staphylococci had a significant positive effect on SCC. Still, differences between CNS species were small. Only the estimate for Staph. simulans appeared to be slightly higher than those for other species. This was surprising, because differences in association with MY were found between species and we expected that the more-virulent pathogens would increase SCC and decrease MY. We checked for possible confounding on MY by excluding this covariate from the model, but this changed the estimates only minimally. The 4 most prevalent species were all associated with higher SCC than other CNS and C. bovis, but with much lower SCC than Staph. aureus. Most previous articles reported significant increases in SCC for CNS-infected udder halves but insignificant differences between species (Leitner et al., 2004b, 2007; Moroni et al., 2005b). Some authors did find differences between species, but the direction of these differences varied. Contreras et al. (1999), for instance, observed higher SCC for Staph. epidermidis-infected udder halves relative to other CNS species, whereas Moroni et al. (2005a) reported higher SCC of Staph. caprae-infected udder halves than of udder halves infected with Staph. epidermidis or other CNS species. In cows, Thorberg et al. (2009) reported no difference in SCC between CNS species, but Supré et al. (2011) found that Staph. chromogenes, Staph. simulans, and Staph. xylosus increase quarter SCC more than other species, to a level comparable with that of Staph. aureus.

In our study, right udder halves had significantly higher SCC than left udder halves. The effect on $\log _{10^{-}}$ transformed SCC was not large in an absolute sense $(\beta$ $=0.040 ; 95 \%$ CI: 0.006 to 0.073 ) but this finding was interesting nevertheless. Contreras et al. (1999) also reported higher SCC for right udder halves than for left udder halves, regardless of infectious status. In cows, right quarters also have higher SCC than left quarters, but this is accompanied by higher infection rate in right quarters, especially by Staph. aureus (Barkema et al., 1997; Zadoks et al., 2001). This may be explained by 
the lying behavior of cows (Kikkers et al., 2006) or by transmission via milking machine liners (Zadoks et al., 2001). In contrast, in hand-milked dairy goats, left udder halves are significantly more often infected than right halves, which could be attributed to the fact that most milkers are right-handed and consequently milk the right mammary glands more thoroughly than the left mammary glands (Boscos et al., 1996). Further study is needed to determine if the higher SCC in right udder halves in goats was caused by a preference for lying on one side or by factors associated with milking.

\section{Association with MY}

The finding that Staph. caprae was associated with more milk, whereas Staph. xylosus was associated with less milk (albeit insignificantly) was unexpected. In a previous study, we analyzed the effect of CNS as a group on MY and found no effect (Koop et al., 2010). The present study shows that the effects of the different CNS species seem to level out when the effect of CNS infection is included as a group, and it stresses the need for species-specific research. Moroni et al. (2005a) found no significant relationship between CNS infection and MY. Leitner et al. (2004) did report some MY decrease associated with CNS infection, but did not report any differences between CNS species. In another study (Leitner et al., 2004a), a decreased MY was observed for CNS-infected udder halves using a half udder design but the number of animals was too small to report differences between CNS species.

The positive relationship of Staph. caprae infection with MY was surprising. In addition, Staph. simulans was associated with higher MY, but not significantly so. In cows, a positive association of infection with MY has been reported for CNS as a group, but the association is not species specific (Compton et al., 2007; Schukken et al., 2009; Piepers et al., 2010). Apparently, minor pathogens can be associated with higher MY. Previously, we discussed the positive association of $C$. bovis with MY (Koop et al., 2010), which was also reported in this paper (Figure 1b). Two explanations were hypothesized to explain this finding: (1) higher-producing animals may be at higher risk for infection, or (2) infection with a minor pathogen has a positive effect on milk production; for instance, through protection against clinical or subclinical IMI with major pathogens, as reported by Piepers et al. (2010) in dairy heifers. The same hypotheses may explain our finding that Staph. caprae was associated with higher MY. Perhaps in higher producing goats, a shift occurs in the composition of the milk, so that substrates that can be used by Staph. caprae, but not by other species, are available in higher con- centrations, thus favoring infection with this species. On the other hand, Staph. caprae may prevent infection with major pathogens, most importantly Staph. aureus. The ability to form a biofilm is a common attribute of Staph. aureus, but Staph. caprae is also capable of biofilm formation (Allignet et al., 2001). It may be that in this way Staph. caprae occupies the niche for Staph. aureus. Further study of Staph. caprae and its virulence factors is needed to clarify mechanisms behind our observations.

In CNS research, it is difficult to obtain sample sizes large enough to obtain significant species-specific results because the large number of CNS species makes the number of isolates per species small. Furthermore, because the observed species distribution cannot be predicted, power calculations are impossible. The abundance of Staph. caprae and C. bovis in our sample made the positive effects of these species on MY become statistically significant, but the negative associations of Staph. xylosus and Staph. aureus with MY were not significant because the number of animals infected with these species was too small. Still, based on the $\beta$-estimate and accompanying standard error, we can calculate that the probability that the true effect of these species in the population is -0.5 or lower is $23 \%$ for Staph. aureus and 31\% for Staph. xylosus. This implies that, although we found no evidence in this study for significant MY losses associated with Staph. aureus or Staph. xylosus infection, it is quite possible that meaningful MY losses are associated with infection by these species.

\section{CONCLUSIONS}

The most prevalent CNS species in Dutch dairy goats were Staph. caprae, Staph. epidermidis, Staph. simulans, and Staph. xylosus, but large variation in species distribution was observed between herds. Staphylococcus caprae and Staph. xylosus tended to cause more persistent infections, but differences between species were nonsignificant. The association of CNS species with SCC was significant, but was much weaker than the effect of Staph. aureus. Staphylococcus caprae was associated with a significantly higher MY and Staph. xylosus with a lower MY than noninfected goats, but differences in effect on MY between other CNS species were small. Overall, CNS species in goats can be considered as minor pathogens because of their limited pathogenicity, but more research is needed to confirm and elucidate differences in effect on MY between the species. Because of the large number of CNS species able to cause IMI in goats, the number of infected glands per species quickly becomes very small. Therefore, in 
future research, large sample sizes or meta-analyses are needed to obtain precise species-specific estimates.

\section{ACKNOWLEDGMENTS}

Lars Hulpio (Department of Reproduction, Obstetrics, and Herd Health, Faculty of Veterinary Medicine, Ghent University, Merelbeke, Belgium) is acknowledged for his excellent laboratory assistance. This research was financially supported by the Dutch Dairy Board and the Dutch Association for Quality Assurance in Goat Farming (VKGN).

\section{REFERENCES}

Allignet, J., S. Aubert, K. G. H. Dyke, and N. El Solh. 2001. Staphylococcus caprae strains carry determinants known to be involved in pathogenicity: A gene encoding an autolysin-binding fibronectin and the ica operon involved in biofilm formation. Infect. Immun. 69:712-718.

Arciola, C. R., D. Campoccia, Y. H. An, L. Baldassarri, V. Pirini, M. E. Donati, F. Pegreffi, and L. Montanaro. 2006. Prevalence and antibiotic resistance of 15 minor staphylococcal species colonizing orthopedic implants. Int. J. Artif. Organs 29:395-401.

Baele, M., P. Baele, M. Vaneechoutte, V. Storms, P. Butaye, L. A. Devriese, G. Verschraegen, M. Gillis, and F. Haesebrouck. 2000. Application of tRNA intergenic spacer PCR for identification of Enterococcus species. J. Clin. Microbiol. 38:4201-4207.

Barkema, H. W., Y. H. Schukken, T. J. G. M. Lam, D. T. Galligan, M. L. Beiboer, and A. Brand. 1997. Estimation of interdependence among quarters of the bovine udder with subclinical mastitis and implications for analysis. J. Dairy Sci. 80:1592-1599.

Bergonier, D., R. de Cremoux, R. Rupp, G. Lagriffoul, and X. Berthelot. 2003. Mastitis of dairy small ruminants. Vet. Res. 34:689-716.

Boscos, C., A. Stefanakis, C. Alexopoulos, and F. Samartzi. 1996. Prevalence of subclinical mastitis and influence of breed, parity, stage of lactation and mammary bacteriological status on Coulter Counter counts and California Mastitis Test in the milk of Saanen and autochthonous Greek goats. Small Rumin. Res. 21:139-147.

Compton, C. W. R., C. Heuer, K. Parker, and S. McDougall. 2007. Epidemiology of mastitis in pasture-grazed peripartum dairy heifers and its effects on productivity. J. Dairy Sci. 90:4157-4170.

Contreras, A., J. C. Corrales, A. Sánchez, and D. Sierra. 1997. Persistence of subclinical intramammary pathogens in goats throughout lactation. J. Dairy Sci. 80:2815-2819.

Contreras, A., C. Luengo, A. Sánchez, and J. C. Corrales. 2003. The role of intramammary pathogens in dairy goats. Livest. Prod. Sci. 79:273-283.

Contreras, A., M. J. Paape, and R. H. Miller. 1999. Prevalence of subclinical intramammary infection caused by Staphylococcus epidermidis in a commercial dairy goat herd. Small Rumin. Res. 31:203-208.

Contreras, A., D. Sierra, A. Sánchez, J. C. Corrales, J. C. Marco, M. J. Paape, and C. Gonzalo. 2007. Mastitis in small ruminants. Small Rumin. Res. 68:145-153.

Deinhofer, M., and A. Pernthaner. 1995. Staphylococcus spp. as mastitis-related pathogens in goat milk. Vet. Microbiol. 43:161-166.

Devriese, L. A., B. Poutrel, R. Kilpper-Balz, and K. H. Schleifer. 1983. Staphylococcus gallinarum and Staphylococcus caprae, two new species from animals. Int. J. Syst. Bacteriol. 33:480-486.

Harrell, F. E. 2004. Hmisc S function library. Accessed Jun. 13, 2012. http://biostat.mc.vanderbilt.edu/s/Hmisc.

Hogan, S. J., R. N. González, R. J. Harmon, S. C. Nickerson, S. G. Oliver, J. W. Pankey, and K. L. Smith. 1999. Laboratory Handbook on Bovine Mastitis. Rev. ed. National Mastitis Council, Verona, WI.
Kikkers, B. H., L. Ózsvári, F. J. C. M. van Eerdenburg, Á. C. Bajcsy, and O. Szenci. 2006. The influence of laterality on mastitis incidence in dairy cattle - Preliminary study. Acta Vet. Hung. 54:161-171.

Koop, G., T. van Werven, H. J. Schuiling, and M. Nielen. 2010. The effect of subclinical mastitis on milk yield in dairy goats. J. Dairy Sci. 93:5809-5817.

Leitner, G., U. Merin, A. Glickman, L. Weisblit, O. Krifucks, A. Shwimmer, and A. Saran. 2004. Factors influencing milk quantity and quality in Assaf sheep and goat crossbreds. S. Afr. J. Anim. Sci. 34:162-164.

Leitner, G., U. Merin, Y. Lavi, A. Egber, and N. Silanikove. 2007. Aetiology of intramammary infection and its effect on milk composition in goat flocks. J. Dairy Res. 74:186-193.

Leitner, G., U. Merin, and N. Silanikove. 2004a. Changes in milk composition as affected by subclinical mastitis in goats. J. Dairy Sci. $87: 1719-1726$.

Leitner, G., U. Merin, N. Silanikove, E. Ezra, M. Chaffer, N. Gollop, M. Winkler, A. Glickman, and A. Saran. 2004b. Effect of subclinical intramammary infection on somatic cell counts. NAGase activity and gross composition of goats' milk. J. Dairy Res. 71:311-315.

Maisi, P., and I. Riipinen. 1991. Pathogenicity of different species of staphylococci in caprine udder. Br. Vet. J. 147:126-132.

Moroni, P., G. Pisoni, M. Antonini, G. Ruffo, S. Carli, G. Varisco, and P. Boettcher. 2005a. Subclinical mastitis and antimicrobial susceptibility of Staphylococcus caprae and Staphylococcus epidermidis isolated from two Italian goat herds. J. Dairy Sci. 88:1694-1704.

Moroni, P., G. Pisoni, G. Ruffo, and P. Boettcher. 2005b. Risk factors for intramammary infections and relationship with somatic cell counts in Italian dairy goats. Prev. Vet. Med. 69:163-173.

Onni, T., G. Sanna, G. P. Cubeddu, G. Marogna, S. Lollai, G. Leori, and S. Tola. 2010. Identification of coagulase-negative staphylococci isolated from ovine milk samples by PCR-RFLP of 16S rRNA and gap genes. Vet. Microbiol. 144:347-352.

Park, J. Y., L. K. Fox, K. S. Seo, M. A. McGuire, Y. H. Park, F. R. Rurangirwa, W. M. Sischo, and G. A. Bohach. 2011. Comparison of phenotypic and genotypic methods for the species identification of coagulase-negative staphylococcal isolates from bovine intramammary infections. Vet. Microbiol. 147:142-148.

Petrie, A., and P. Watson. 2006. Measuring agreement. Pages196-201 in Statistics for Veterinary and Animal Science. 2nd ed. Blackwell Publishing, Oxford, UK.

Piepers, S., G. Opsomer, H. W. Barkema, A. De Kruif, and S. De Vliegher. 2010. Heifers infected with coagulase-negative staphylococci in early lactation have fewer cases of clinical mastitis and higher milk production in their first lactation than noninfected heifers. J. Dairy Sci. 93:2014-2024.

Piessens, V., E. Van Coillie, B. Verbist, K. Supré, G. Braem, A. Van Nuffel, L. De Vuyst, M. Heyndrickx, and S. De Vliegher. 2011. Distribution of coagulase-negative Staphylococcus species from milk and environment of dairy cows differs between herds. J. Dairy Sci. 94:2933-2944.

Pilipčincová, I., M. Bhide, E. Dudriková, and M. Trávniček. 2010. Genotypic characterization of coagulase-negative staphylococci isolated from sheep milk in Slovakia. Acta Vet. (Brno) 79:269-275.

Pinheiro, J., D. Bates, S. DebRoy, D. Sarkar, and the R core team. 2009. NLME: Linear and nonlinear mixed effects models; R package version 3.1-96. R Foundation for Statistical Computing, Vienna, Austria.

Poutrel, B. 1984. Udder infection of goats by coagulase-negative staphylococci. Vet. Microbiol. 9:131-137.

Pyörälä, S., and S. Taponen. 2009. Coagulase-negative staphylococciEmerging mastitis pathogens. Vet. Microbiol. 134:3-8.

Ross, T. L., E. P. Fuss, S. M. Harrington, M. Cai, T. M. Perl, and W. G. Merz. 2005. Methicillin-resistant Staphylococcus caprae in a neonatal intensive care unit. J. Clin. Microbiol. 43:363-367.

Sampimon, O. C., R. N. Zadoks, S. De Vliegher, K. Supré, F. Haesebrouck, H. W. Barkema, J. Sol, and T. J. G. M. Lam. 2009. Performance of API Staph ID 32 and Staph-Zym for identification of coagulase-negative staphylococci isolated from bovine milk samples. Vet. Microbiol. 136:300-305. 
Schukken, Y. H., R. N. González, L. L. Tikofsky, H. F. Schulte, C. G. Santisteban, F. L. Welcome, G. J. Bennett, M. J. Zurakowski, and R. N. Zadoks. 2009. CNS mastitis: Nothing to worry about? Vet. Microbiol. 134:9-14.

Supré, K., S. De Vliegher, O. C. Sampimon, R. N. Zadoks, M. Vaneechoutte, M. Baele, E. De Graef, S. Piepers, and F. Haesebrouck. 2009. Technical note: Use of transfer RNA-intergenic spacer PCR combined with capillary electrophoresis to identify coagulase-negative Staphylococcus species originating from bovine milk and teat apices. J. Dairy Sci. 92:3204-3210.

Supré, K., F. Haesebrouck, R. N. Zadoks, M. Vaneechoutte, S. Piepers, and S. De Vliegher. 2011. Some coagulase-negative Staphylococcus species affect udder health more than others. J. Dairy Sci. 94:2329-2340.
Thorberg, B.-M., M.-L. Danielsson-Tham, U. Emanuelson, and K. Persson Waller. 2009. Bovine subclinical mastitis caused by different types of coagulase-negative staphylococci. J. Dairy Sci. 92:4962-4970.

Valle, J., S. Piriz, R. de la Fuente, and S. Vadillo. 1991. Staphylococci isolated from healthy goats. Zentralbl. Veterinarmed. B. 38:81-89.

Zadoks, R. N., H. G. Allore, H. W. Barkema, O. C. Sampimon, G. J. Wellenberg, Y. T. Gröhn, and Y. H. Schukken. 2001. Cow- and quarter-level risk factors for Streptococcus uberis and Staphylococcus aureus mastitis. J. Dairy Sci. 84:2649-2663.

Zadoks, R. N., and J. L. Watts. 2009. Species identification of coagulase-negative staphylococci: Genotyping is superior to phenotyping. Vet. Microbiol. 134:20-28. 